\title{
Effect of Waste Tire Reinforcement with and Without Cement Additives on Peat Strength Improvement
}

\author{
Nur Amalina Hilwane ${ }^{1, a^{*}}$, Norazzlina M. Sa'don ${ }^{2, b^{*}}$, Abdul Razak Abdul Karimº \\ ${ }^{1,2,3}$ Faculty of Engineering, Universiti Malaysia Sarawak, 94300 Kota Samarahan, \\ Sarawak, Malaysia \\ a*nuramalinahilwane@hotmail.com, bmsazzlin@unimas.my, cakarazak@unimas.my
}

Keywords: cement; improvement; peat; shear strength; stabilization; waste tires.

\begin{abstract}
This paper presents the peat ground improvement techniques using waste-tire as a fibre reinforced material. In this study, two sizes of the waste-tire are chosen, which are $0.05 \mathrm{~mm}$ and 1-3 mm, respectively. The collected peat is classified as Sapric peat with the degree of decomposition of $\mathrm{H} 7$ based on von Post classification with high moisture content of $400 \%$ was recorded. The Sapric peat is treated with the waste-tire at designated percentages of $5 \%, 10 \%$ and $15 \%$ with the addition of 5\% of cement acting as a binder. The untreated and treated peat without and with cement content are compacted at the optimum moisture content for both the Unconfined Compressive Strength (UCS) test and Direct Shear Box Test. The specimens were air-cured for 7, 28, 56, and 90 days. Hypothetically, higher percentages of rubber improve the shear stress value of the treated peat. According to the results the finer size $(0.05 \mathrm{~mm})$ of the tire produces a higher shear stress, which may due the finer sizes of the waste-tire filled the void between the soil particles. Further, from the 90 days of curing UCS results, there is a significant increase in compressive strength with the increase percentage of the waste-tire peat mixed samples. In summary, soil stabilized by the scrap-tire is believed to decrease the optimum moisture content and the maximum dry densities, but it helps in increasing the unconfined compressive strength value. Stabilizing by using the tire wastes not only increasing the strength of the soil, but it also helps in reducing the disposal problems.
\end{abstract}

\section{Introduction}

Peat is a soil comprises primarily of vegetable tissue in different period of decomposition, accompanied by organic odour, a spongy consistency, and fibrous to amorphous texture, and a dark brown to black colour [1]. It is a product of accumulation the remnants of the decompose vegetation, with a high organic content due to the effect of the partial decaying and rupture process of mosses, sedges, trees, and the plants that grow in marshes and other wet places with the lower oxygen content and high contents of fibrous organic matters [2]. ASTM D4427 [3] stated that there are three categories of peat, namely fibric, hemic and sapric, which are classified based on the fibre and ash, and the acidity of the soil. Fibric soil contents more than $67 \%$ of the fibre, with a high organic and fibre content. Hemic soils represent the intermediate between fibric and sapric which its fibre content is around 33- 67\%. Sapric, on the other hand consists of less than $33 \%$ of its fibrous content. Sapric are highly decomposed material. Its water holding capacity is less than fibric and hemic. Sapric soil is also known to have a low permeability, compressibility, and friction angle while its coefficient of earth pressure is increasing at rest [4]. According to Bell [5], high percentage of moisture and a low dry density cause the soils have a weak shear strength. Shear strength lowers as the moisture and decomposition increases, but a higher mineral content produces a higher shear strength [6]. Peat drainage act as the controlling factor in determining the geotechnical behaviour of the peat. Peat that has high fibre content high in water content are compressible, which results in a lower value in the shear modulus and a higher damping ratio [7]. Subsidence and drainage potential are the most important factors that will influence the potential of peat soils for sustainable reclamation when constructing roads. Excessive settlement will be worsening because of the drainage due to compaction resulting from the expulsion of free pore water by loading. Hence, this will affect the road constructed above the peat if there is no maintenance being carried out. 